\title{
Landscape Diversity as a Screening Tool to Assess Agroecosystems Sustainability; Preliminary Study in Central Italy
}

\author{
Roberto Crosti ${ }^{* 1}$, Vanna Forconi ${ }^{1}$, Carmela Cascone ${ }^{2}$, Francesco Visicchio ${ }^{1}$ \\ ${ }^{1}$ Servizio Agricoltura \\ ${ }^{2}$ Servizio Parchi e Risorse Naturali \\ APAT, Dipartimento Difesa della Natura, Via Curtatone 3, 00185 Roma, Italy
}

Received: 2 December 2006. Accepted: 2 January 2007

\begin{abstract}
Modernization of agricultural activities has strongly modified agricultural landscapes. Intensive agriculture, with the increased use of inorganic fertiliser and density of livestock, affects water quality discharging nutrients such as nitrogen and phosphorus in water bodies. Nutrients in rivers, subsequently, are excellent indicators to assess sustainability/land-use intensity in agroecosystems. Landscape, however, is a dynamic system and is the product of interaction amongst the natural environment and human activities, including farming which is a main driving force. At present not much has been investigated on the predictive role of landscape on land-use intensity. Aim of this study is to determine if, in Italian agroecosystem, landscape complexity can be related to land-use intensity. Indexes of landscape complexity (i.e. edge density, number of patches, Shannon's diversity index, Interspersion-Juxtaposition index) derived by processing Corine Land Cover data (level IV, 1:25.000) of Lazio Region, were related with landuse intensity (values of compounds of nitrogen and phosphorus and other parameters found in rivers monitored in accordance to European Directives on Waste Water). Results demonstrate that some landscape indexes were related to some environment parameters. Consequently landscape complexity, with further investigation, could be an efficient screening tool, at large scale, to assess water quality and ultimately agroecosystems sustainability in the absence of monitoring stations.
\end{abstract}

Key-words: landscape, agroecosystem, diversity, corine, indicator, river basin.

\section{Introduction}

Monitoring environmental quality of a territory is often complex as it includes the analysis of a great number of variables. The analysis of single components of the ecosystem can be made through indicators that, with different precision, can measure directly a specific parameter and indirectly an environmental state to which the parameter is linked. An indicator is a parameter, or a set of parameters, that gives information on the state of a phenomenon or of an area. The significance goes over the property directly associated to the value of the parameter itself (OECD 1993). An indicator needs to be a concise tool but at the same time it needs to be effective in the description. The validity of an indicator can be assessed by its accuracy, meaning the capacity to detect a specific parameter and by its efficiency, meaning the capacity to easily detect the parameter.

In all those areas where human manipulation for agricultural production overlays the natural ecosystem, originating the agroecosystem (Caporali, 2000), agriculture practices can generate more or less impact according to the type of farming procedures undertaken (Altieri, 1995); the impact of the different agriculture practices on environment quality of agroecosystems is measured through different indicators. Water is one of the main renewable elements of agroecosystems, and rivers can be considered as the final basin, in time and space, of pressure and impacts of the surrounding terri- 
tory (Kristensen, 1994; Borgvang et al., 2000).

River pollution due to nitrogen compounds, such as $\mathrm{NH}_{4}$ and $\mathrm{NO}_{3}$, and phosphorous, $\mathrm{P}$, is an effect of intensive use of fertilizers and of the abundance of livestock. The higher the pressure of the agriculture system is on the environment, the higher is the presence of nutrients in rivers. Furthermore, when the disturbance of the field's margin in correspondence with the river's bank is higher, river pollution increases; due to $a b-$ sence of vegetation, in fact, there is a reduced uptake of nutrients before these can reach the river (Siligardi, 1997). Consequently, values of nitrogen and phosphorous are the main indicators used to assess water quality in agroecosystems (Wascher et al., 2000). Water quality, however, of a river body can be also assessed through biotic analysis.

In Italy the Legislative Decree 152/99 made compulsory the monitoring of river bodies so to assess the Water quality. Furthermore the Framework Directive 2000/60/EU points out the necessity of an ecosystem approach of river basin monitoring. Within the agroecosystem, the different agriculture management, the vegetation and the soil use affect the transformation of the landscape/territory. Landscape itself, in fact, can be considered as a representation of the complex interactions between anthropogenic activities and the natural environment (Farina, 2001; Battisti, 2004). Complexity of landscape has been used to assess intensity of land use (Bunce et al., 1993; Roscherwitz et al., 2004, 2005) and to measure water quality (Wiens, 2002; Kearns et al., 2005; Houlahan et al., 2004). Furthermore, many reports and guidelines suggest the use of landscape metrics to measure environmental quality (AA.VV., 2000; Wascher et al., 2000; OECD, 2003 and 2004; EEA report, 2005).

Aim of this preliminary study is to assess whether, in Italian agroecosystems, landscape metric can be associated directly to values of nutrients and of biotic indexes so to be used as an indirect indicator of environment quality in agricultural areas.

In particular this study aims to assess whether between landscape and the environmental quality of the water body:

- there is a "minimal area" suitable to establish a direct relationship;

- a more detailed definition of the landscape, therefore with an higher number of patch

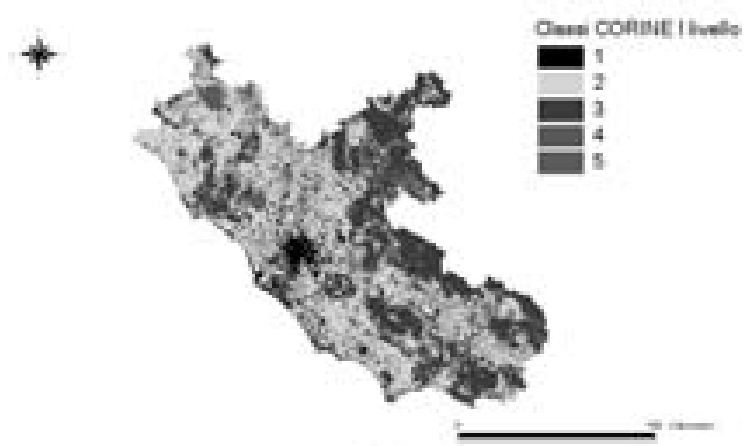

Figure 1. CORINE Land Cover; Level 1, class II (in yellow) agricultural areas of Latium.

types, is more suitable to detect relationships;

- some landscape indexes are more suitable then others to detect relationships.

According to the answer obtained from the previous points, this study aims to verify if landscape metric can be used as an efficient indicator of environmental quality.

\section{Materials and methods}

Latium, in Central Italy, is the Italian Region chosen for this analysis. In Latium, agriculture is an important economic resource and most of its territory is characterised by conventional agricultural practices (Fig. 1).

Within 52 sites, located on water bodies, where there is constant monitoring, according to the D.Lgs. 152/99, we chose 24 that had in the surrounding buffer zone of 3,000 metres the higher values of agriculture areas (measured with CORINE Land Cover-CLC). These 24 sites were the areas investigated for this study (Fig. 2; Tab. 1). For each of the 24 monitoring stations, average values of chemical-physical parameters and indexes (Tab. 2) for the years 2002-20032004 were calculated. Analysis of landscape complexity was developed using CORINE Land Cover database (CLC) 1:25,000 of the Latium Region.

To assess the extent of a "minimum monitoring area" capable of measuring the relation between landscape and environmental quality of the water body, two different buffer areas, around the monitoring station, were analysed: one within $1,000 \mathrm{~m}$ and one within $3,000 \mathrm{~m}$ of radius.

To assess whether a more detailed definition 
Table 1. Rivers and sites of the monitoring stations.

\begin{tabular}{lcc}
\hline Stations location & XUTM ED50 & YUTM ED50 \\
\hline Fiume Amaseno - Madonna del Ponte & 355010 & 4596298 \\
Fiume Amaseno - Mola dell'Abbadia & 349702 & 4591481 \\
Fiume Amaseno - Ponte alle Mole & 349892 & 4594214 \\
Fiume Aniene - Lunghezza & 306666 & 4644528 \\
Fiume Fibreno - Sora - S. Domenico & 381884 & 4617348 \\
Fiume Fiora - Ponte Badia & 223643 & 4702103 \\
Fiume Fiora - Ponte S. Agostino Vecchio & 219947 & 4694853 \\
Fiume Fiora - Ponte S. Pietro & 221372 & 4713435 \\
Fiume Liri - Le Compre & 384322 & 4624548 \\
Fiume Liri - Ponte Corvo - S.G. Incarico & 388623 & 4590273 \\
Fiume Marta - Ponte strada Litoranea & 228593 & 4682212 \\
Fiume Marta - Ponte strada Marta -Tuscania & 245789 & 4706551 \\
Fiume Marta - Ponte strada Viterbo - Tuscania & 243077 & 4699416 \\
Fiume Mignone - a monte conf.fiume Lenta & 253713 & 4670129 \\
Fiume Mignone - loc. Montericcio & 231905 & 4684092 \\
Fiume Mignone - Rota teleferica & 253017 & 4671355 \\
Fiume Sacco - V. Casilina Km 47 conf. Savo & 332043 & 4625233 \\
Fiume Tevere - Ponte Attigliano & 276451 & 4709794 \\
Fiume Tevere - Ponte di Mezzocamino & 285625 & 4631798 \\
Fiume Velino - Antrodoco & 342108 & 4697830 \\
Fiume Velino - Chiesa Nuova & 321419 & 4699875 \\
Fiume Velino - Ponte Ubertini & 314769 & 4708410 \\
Torrente Arrone - SS1 Aurelia & 223380 & 4691381 \\
Torrente Farfa - Ponte Sfondato & 305743 & 4676025
\end{tabular}

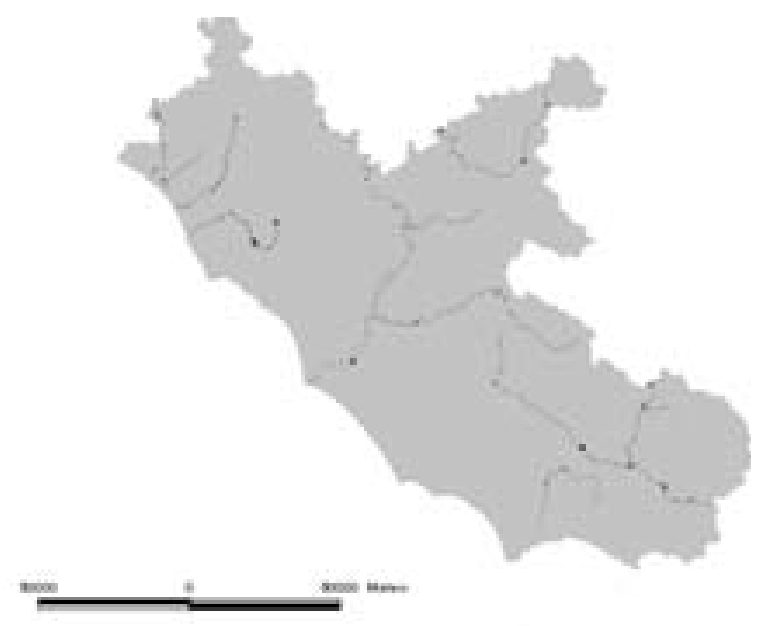

Figure 2. Locations of monitoring stations.

of the landscape is more suitable to detect the relation between landscape and environmental quality of the water body, both buffers were analysed with the Level 1 and 3 of CLC.

The different landscape indexes used in this study are shown in Table 3.

Consequently, each of the 24 sites was associated with different landscape indexes and different environmental parameters and indexes. To determine which landscape parameter is more capable to detect the environmental quality of the water body, excluding the causeeffect relationship, values of landscape metric and environmental data were correlated. Validity of this approach was assessed by the numbers of correlations for each landscape index and values of correlation coefficient. Data were tested with the Pearson correlation (r) for the chemical-physical parameters that are on a continuous scale and with the Spearman correlation (rs) for the environmental indexes that are in classes. Correlation was considered medium (M) for coefficient included between \pm 0.3 and \pm 0.45 and high $(\mathrm{H})$ with coefficient greater than \pm 0.45 .

\section{Results}

Results from the correlation between landscape indexes and environmental quality of the water bodies are shown in Table 4.

In particular, most of the correlations present were medium; the $3,000 \mathrm{~m}$ radius buffer had a greater number of correlation compared to the $1,000 \mathrm{~m}$ buffer; the $1^{\text {st }}$ level CLC had slightly higher number of correlations compared to the $3^{\text {rd }}$ level; the landscape indexes SDI and 
Table 2. Investigated environmental data: chemical-physical parameters and indexes.

\begin{tabular}{|c|c|c|c|c|}
\hline \multirow{2}{*}{$\begin{array}{l}\text { CHEMICAL } \\
\text { PARAMETER }\end{array}$} & \multirow[t]{2}{*}{ IT MEASURES: } & \multirow[t]{2}{*}{ IT INDICATES: } & \multicolumn{2}{|l|}{ RANGE } \\
\hline & & & $\begin{array}{c}\text { Level 1: } \\
\text { high } \\
\text { environmental } \\
\text { quality }\end{array}$ & $\begin{array}{c}\text { Level 5: } \\
\text { low } \\
\text { environmental } \\
\text { quality }\end{array}$ \\
\hline $\mathrm{NH}_{4}^{+}(\mathrm{mg} / \mathrm{l})$ & $\begin{array}{l}\text { Ammonium ion } \\
\text { concentration in waters }\end{array}$ & $\begin{array}{l}\text { It's an indicator of } \\
\text { agricultural pollution } \\
\text { and bacterial activity }\end{array}$ & $<0,03$ & $>1,5$ \\
\hline $\mathrm{NO}_{3}^{-}(\mathrm{mg} / \mathrm{l})$ & Nitrates concentration & $\begin{array}{l}\text { It's an indicator } \\
\text { of both agricultural and } \\
\text { organic pollution }\end{array}$ & $<0,3$ & $>10,0$ \\
\hline P Total phosphorus & Total phosphorus & $\begin{array}{l}\text { It's an indicator of both } \\
\text { urban and agricultural } \\
\text { pollution; trophic level }\end{array}$ & $<0,07$ & $>0,6$ \\
\hline \multicolumn{5}{|l|}{ INDEX } \\
\hline $\begin{array}{l}\text { LIM Macrodescriptors } \\
\text { Pollution Level }\end{array}$ & $\begin{array}{l}\text { Synthetic Index of } \\
\text { pollution }\end{array}$ & $\begin{array}{l}\text { Chemical-physical } \\
\text { pollution }\end{array}$ & 1 & 5 \\
\hline $\begin{array}{l}\text { IBE Extended } \\
\text { Biotic Index }\end{array}$ & $\begin{array}{l}\text { Community structure } \\
\text { of macroinvertebrates }\end{array}$ & Water body quality & 1 & 5 \\
\hline $\begin{array}{l}\text { SECA Ecological } \\
\text { State of rivers }\end{array}$ & $\begin{array}{l}\text { It's an integration of } \\
\text { LIM and IBE }\end{array}$ & Ecological State & 1 & 5 \\
\hline
\end{tabular}

Table 3. Landscape indexes used in the study.

\begin{tabular}{lll}
\hline CODE & Description & Range \\
\hline $\begin{array}{l}\text { LSI } \\
\text { Landscape Shape Index }\end{array}$ & $\begin{array}{l}\text { It provides a simple measure } \\
\text { of class aggregation or } \\
\text { clumpiness }\end{array}$ & $\begin{array}{l}1=\text { when the buffer consists of a single square } \\
\text { or maximally compact patch of the corresponding type }\end{array}$ \\
& $\begin{array}{l}\text { LSI increases without limit as the patch type beco- } \\
\text { mes more disaggregated (i.e., the length of edge } \\
\text { within the landscape of the corresponding patch type } \\
\text { increases) }\end{array}$ \\
\hline
\end{tabular}

SDI

Shannon's Diversity Index

It's a measure of the number $0=$ when the buffer contains only 1 patch

of patch types in the landscape

It increases as the number of different patch types increases and/or the proportional distribution of area among patch types becomes more equitable

\begin{tabular}{ll}
\hline SEI & It's a measure of the \\
Shannon's Evenness Index & distribution of area
\end{tabular} $0=$ when the buffer contains only 1 patch and among different patch types in the landscape approaches 0 as the distribution of area among the different patch types becomes increasingly uneven $1=$ when distribution of area among patch types is perfectly even (i.e., proportional abundances are the same)

\begin{tabular}{lll}
\hline ED & $\begin{array}{l}\text { It reports edge length on } \\
\text { a per unit area basis that } \\
\text { facilitates comparison } \\
\text { among landscapes of } \\
\text { varying size }\end{array}$ & $\begin{array}{l}0=\text { when there is no class edge in the landscape; } \\
\text { that is, when the entire buffer and buffer border } \\
\text { consist of the corresponding patch type and the user } \\
\text { specifies that none of the buffer boundary and } \\
\text { background edge can be treated as edge }\end{array}$ \\
\hline $\begin{array}{ll}\text { Total edge at the class level } \\
\text { is an absolute measure of } \\
\text { total edge length of a } \\
\text { particular patch type or } \\
\text { all the patches in the }\end{array}$ & $\begin{array}{l}0=\text { when there is no class edge in the buffer; that is, } \\
\text { landscape }\end{array}$ & $\begin{array}{l}\text { the corresponding patch type and the user specifies } \\
\text { that none of the buffer boundary and background } \\
\text { edge be treated as edge }\end{array}$
\end{tabular}


Table 3 (continued)

\begin{tabular}{|c|c|c|}
\hline $\begin{array}{l}\text { MPS } \\
\text { Mean Patch Size }\end{array}$ & $\begin{array}{l}\text { It equals the total class area } \\
\text { divided by the total number } \\
\text { of patches of the class }\end{array}$ & MPS $>0$, without limit \\
\hline $\begin{array}{l}\text { NUMP } \\
\text { Number of Patches }\end{array}$ & $\begin{array}{l}\text { It equals the number of } \\
\text { patches of the corresponding } \\
\text { patch type. }\end{array}$ & $\begin{array}{l}1 \text { = when the buffer contains only } 1 \text { patch of the } \\
\text { corresponding patch type; that is, when the class } \\
\text { consists of a single patch. } \\
\text { It increases, without limit, as the number of patches } \\
\text { increases }\end{array}$ \\
\hline $\begin{array}{l}\text { MSI } \\
\text { Mean Shape Index }\end{array}$ & $\begin{array}{l}\text { It measures the average } \\
\text { patch shape for a particular } \\
\text { patch type or for all patches } \\
\text { in the buffer. It corrects for } \\
\text { the size problem of the } \\
\text { perimeter-area ratio index } \\
\text { by adjusting for a square } \\
\text { (or almost square) standard }\end{array}$ & $\begin{array}{l}1 \text { = when all patches in the buffer are circular } \\
\text { (vector) or square (raster); it increases without limit } \\
\text { as the patch shapes become more irregular }\end{array}$ \\
\hline $\begin{array}{l}\text { AWMSI } \\
\text { Area Weighted Mean } \\
\text { Shape Index }\end{array}$ & $\begin{array}{l}\text { It equals the average Shape } \\
\text { Index of patches, weighted } \\
\text { by patch area so that larger } \\
\text { patches weight more than } \\
\text { smaller ones. }\end{array}$ & $\begin{array}{l}1 \text { = when all patches in the buffer are circular } \\
\text { (vector) or square (raster); } \\
\text { AWMSI increases without limit as the patch shapes } \\
\text { become more irregular }\end{array}$ \\
\hline $\begin{array}{l}\text { AWMPFD } \\
\text { Area Weighted Mean } \\
\text { Patch Fractal } \\
\text { Dimension }\end{array}$ & $\begin{array}{l}\text { It equals the average patch } \\
\text { fractal dimension of patches } \\
\text { in the landscape, weighted } \\
\text { by patch area. }\end{array}$ & $\begin{array}{l}\text { AWMPFD approaches } 1 \text { for shapes with very simple } \\
\text { perimeters such as circles or squares, and } \\
\text { approaches } 2 \text { for shapes with highly convoluted, } \\
\text { plane-filling perimeters }\end{array}$ \\
\hline $\begin{array}{l}\text { IJI } \\
\text { Interspersion } \\
\text { Juxtaposition Index }\end{array}$ & $\begin{array}{l}\text { It is based on patch } \\
\text { adjacencies. It rather isolates } \\
\text { the interspersion or intermi- } \\
\text { xing of patch types. }\end{array}$ & $\begin{array}{l}100=\text { when the corresponding patch type is equally } \\
\text { adjacent to all other patch types (i.e., maximally } \\
\text { interspersed and juxtaposed to other patch types). } \\
\text { IJI approaches } 0 \text { when the corresponding patch type } \\
\text { is adjacent to only } 1 \text { other patch type and the num- } \\
\text { ber of patch types increases }\end{array}$ \\
\hline $\begin{array}{l}\text { MNN } \\
\text { Mean Nearest-Neighbor } \\
\text { Distance }\end{array}$ & $\begin{array}{l}\text { It equals the sum of the } \\
\text { distance to the nearest } \\
\text { neighboring patch of the } \\
\text { same type. }\end{array}$ & $\begin{array}{l}\text { MNN }>0 \text {, without limit. } \\
\text { MNN approaches } 0 \text { as the distance to the nearest } \\
\text { neighbour decreases }\end{array}$ \\
\hline
\end{tabular}

SEI had higher numbers of correlations in particular with $\mathrm{NH}_{4}, \mathrm{NO}_{3}$ and $\mathrm{P}$.

IBE was associated only once in the $3,000 \mathrm{~m}$ buffer at the $1^{\text {st }}$ level.

\section{Discussion}

As shown in other studies already mentioned in this paper, this study also shows presence of correlation (which does not imply causation) between landscape indexes such as SDI and SEI and the chemical-physical parameters such as $\mathrm{NH}_{4}, \mathrm{NO}_{3}$ and $\mathrm{P}$, which are usually used as indicators of land use pressure in agroecosystems.

The indexes SDI and SEI are commonly used to characterise species diversity and even- ness in biotic communities and are also used to quantify landscape diversity. The first index is a measure of relative patch diversity, or the proportional abundance of each patch type within the landscape, while the latter is a measure of patch distribution and abundance, or the measurement of the distribution of areas among patch types within the landscape.

In river bodies within agroecosystems, large values of chemical-physical parameters are associated with large values of SDI and SEI. The analysis of other landscape indexes (such as NUMP, TE and ED) showed that the presence of many small patches was associated with environmental parameters. A 1,000 m-radius buffer is not sufficient to detect solid relationship between landscape and the environmental 
Table 4. Correlation $\mathrm{r}$ and $\mathrm{rs}$ between environmental data and landscape indexes; $\mathrm{M}$ medium, $\mathrm{H}$ high correlation coefficent.

\begin{tabular}{|c|c|c|c|c|c|c|c|c|c|c|c|c|c|c|}
\hline \multirow[t]{2}{*}{ Level } & \multirow[t]{2}{*}{ Buffer } & \multirow{2}{*}{$\begin{array}{l}\text { Environmental } \\
\text { data }\end{array}$} & \multicolumn{11}{|c|}{ Landscape indexes } & \\
\hline & & & MNN & IJI & NUMP & MPS & $\mathrm{TE}$ & ED & MSI & AWMSI & AWMPFD & SDI & SEI & LSI \\
\hline \multirow{2}{*}{$\frac{\vec{D}}{\stackrel{\vec{d}}{u}}$} & $\begin{array}{l}\Xi \\
\S \\
\varrho\end{array}$ & 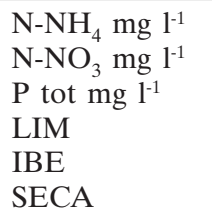 & & & $\mathrm{H}$ & & $\begin{array}{l}\mathrm{M} \\
\mathrm{H}\end{array}$ & $\begin{array}{l}\mathrm{H} \\
\mathrm{M}\end{array}$ & & & & M & & $\mathrm{H}$ \\
\hline & 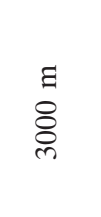 & 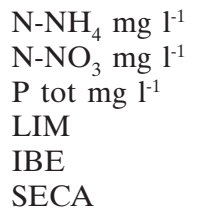 & & & M & $-\mathrm{M}$ & M & M & & $-\mathrm{M}$ & $-\mathrm{M}$ & $\begin{array}{l}\mathrm{M} \\
\mathrm{M} \\
\mathrm{H}\end{array}$ & $\begin{array}{l}\mathrm{M} \\
\mathrm{H} \\
\mathrm{M}\end{array}$ & M \\
\hline \multirow{2}{*}{$\begin{array}{l}\overrightarrow{0} \\
\overrightarrow{0} \\
\overrightarrow{0} \\
-1\end{array}$} & 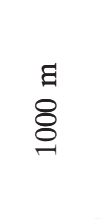 & 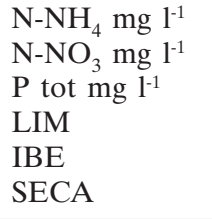 & M & & M & & M & M & & & & $\begin{array}{l}\mathrm{M} \\
\mathrm{M} \\
\mathrm{M}\end{array}$ & M & M \\
\hline & $\begin{array}{l}\Xi \\
8 \\
8 \\
\text { ஜ }\end{array}$ & 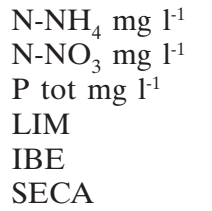 & $-\mathrm{H}$ & $\mathrm{M}$ & $\begin{array}{l}\mathrm{H} \\
\mathrm{M}\end{array}$ & $-\mathrm{M}$ & $\mathrm{H}$ & M & & $\mathrm{H}$ & $\mathrm{H}$ & $\begin{array}{l}\mathrm{M} \\
\mathrm{H} \\
\mathrm{M}\end{array}$ & $\begin{array}{l}\mathrm{H} \\
\mathrm{M} \\
\mathrm{M}\end{array}$ & M \\
\hline
\end{tabular}

Figure 3. Level 1 and 3 of CLC and 1,000 $\mathrm{m}$ and 3,000 $\mathrm{m}$ buffers.

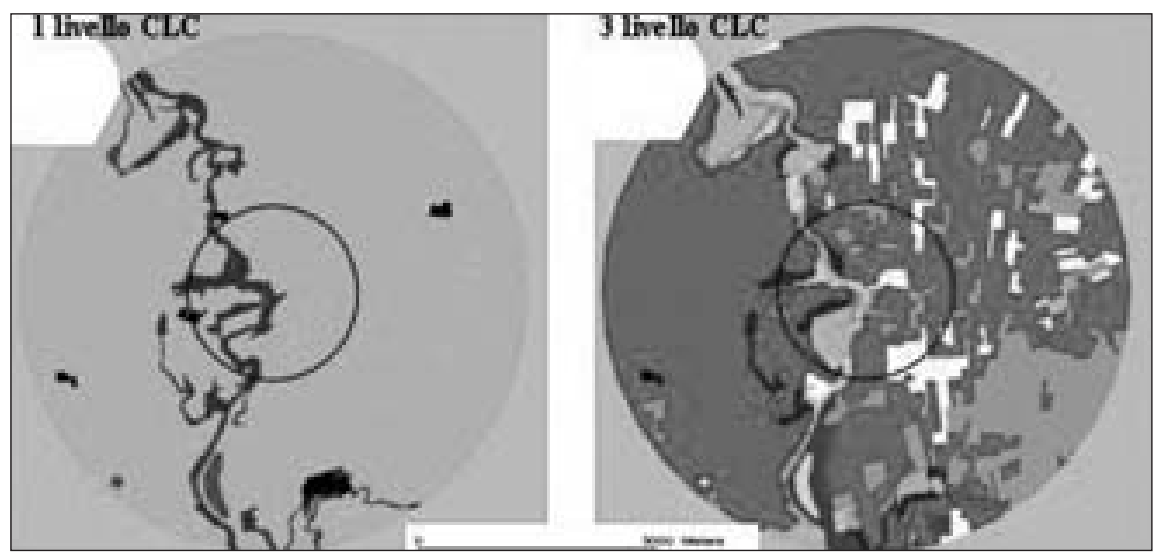

quality of the water body while there is no need of a detailed definition of the landscape as analysis of the $1^{\text {st }}$ level of CLC is sufficient to detect possible relationships.

Numbers of correlations and values of coefficient remain however low, and this could be due to the fact that, due to the absence of longterm monitoring, an average of only 3 years of monitoring may not be sufficient to properly represent the water quality. Furthermore, values of monthly monitoring could easily be influenced by the seasonal flows. According to our preliminary study, at present, landscape metrics only partially can efficently describe water quality within agroecosystems and could just be useful as an initial screening tool in the absence of 
monitoring stations. "[...] however there are areas - and landscape is one of them - for which the definition of operational indicators remains a major challenge" (AA.VV. 2000).

\section{Acknowledgements}

We are grateful to the following colleagues that did contribute to the realization of this study. In APAT: Maria Giuseppina Farrace, Giovanni Finocchiaro, Antonella Arcangeli, Matteo Guccione, Maria Cecilia Natalia and Carlo Jacomini and in ARPA: Silvia Castelli and Giorgio Catenacci. A particular thanks to Angelo Lisi, with whom this study was initially planned.

\section{References}

AA.VV. 2000. From land cover to landscape diversity in the European Union. Report of the European Commission.

Altieri M.A. 1995. Agroecology: The science of sustainable agriculture. Westview Press, Boulder, CO.

Battisti C. 2004. Frammentazione ambientale, connettività, reti ecologiche. Provincia di Roma.

Borgvang S.A., Selvik J.R. 2000. Development of HARP Guidelines, SFT report 1759-2000.

Bunce R.L., Ryskowski L., Paoletti M.G. 1993. Landscape ecology and Agroecosystemns. Lewis Publishers.

Caporali F. 2000. Ecologia per l'agricoltura. Utet.

EEA (2005) Agriculture and environment in EU-15- the Irena indicator report.

Houlahan J.E., Findlay C.S. 2004. Estimating the 'critical' distance at which adjacent land-use degrades wetland and sediment quality. Landscape Ecology, 19:677-690.

Kearns F.R., Kelly N.M., Carter J.L., Resh V.H. 2005. A method for the use of landscape metrics in freshwater research and management. Landscape Ecology, 20:113-125.

Kristensen P., Hansen O.H. 1994. European Rivers and Lakes - Assessment of their environmental state. European Environment Agency, EEA Environmental Monographs.

OECD 1993. OECD core set of indicators for environmental performance reviews. OECD Environment Monographs No. 83.

OECD 2003. Agriculture and Land Conservation. Proceedings. Japan.

OECD 2004. Farm management indicators and the environment. Prooceedings. New Zealand.

Farina A. 2001. Ecologia del paesaggio, principi, metodi e applicazioni. Utet.

Roscherwitz I., Carsten T., Tscharntke T. 2005. Are landscape complexity and farm specialisation related to land-use intensity of annual crop fields? Agriculture, Ecosystems and Environment, 105:87-99.

Roscherwitz I., Gabriel D., Tscharntke T., Carsten T. 2004. The effect of landscape complexity on arable weed species diversity in organic and conventional farming. Journal of Applied Ecology, 42:873-882.

Siligardi M. 1997. Ecologia del paesaggio e sistemi fluviali. In: V. Ingegnoli (ed.): Esercizi di Ecologia del Paesaggio. Città Studi Edizioni.

Wascher D.W. 2000. Agri-environmental indicators for suistanable agriculture in Europe. ECNC Technical report.

Wiens J.A. 2002. Riverine landscapes: taking landscape ecology into the water. Freshwater Biology, 47:501515 . 